\title{
PERKEMBANGAN PESANTREN DI ERA TEKNOLOGI
}

\section{Mohammad Arif}

STAIN Tulungagung

Jl. Mayor Sujadi Timur No. 46 Tulungagung 66221

Email: m_arif_smnp@yahoo.co.id

\begin{abstract}
ABSTRAK
Tulisan ini bertujuan mendiskusikan kemungkinan lembaga pendidikan pesantren merespons kemajuan teknologi dan informasi yang dapat memberikan warna baru terhadap keberadaannya di Indonesia. Oleh masyarakat umum, pesantren dinilai masih sangat terbelakang dalam penguasaan teknologi, khususnya dalam pemanfaatan teknologi informasi untuk pendidikan. Padahal potensi perbaikan itu ada ketika UU Siskdiknas No 20 tahun 2003 pasal 30 ayat 4, menempatkan posisi pesantren sejajar dengan lembaga pendidikan lain yang ada di Indonesia. Kini, pesantren tidak hanya identik sebagai lembaga pendidikan yang mengajarkan ilmu-ilmu keagamaan saja tetapi juga mengembangkan ilmu pengetahuan umum termasuk pemanfaatan teknologi informasi untuk pendidikan. Oleh karena itu, pesantren tidak boleh menyia-nyiakan kesempatan ini. Pesantren harus selalu meng-update informasi-nformasi yang mereka pergunakan. Dengan teknologi informasi pesantren dapat terbantu dalam melakukan penyebaran informasi mengenai profil, kegiatan dan manajemen pesantren dalam pengembangan SDM dan pendidikan.
\end{abstract}

Kata Kunci: Pesantren, Teknologi, Sumber Daya Manusia

\section{ABSTRACT}

This paper aims to discuss the possibility of boarding education institutions to respond to technological advances and information that can give a new color to its existence in Indonesia. By the general public, pesantren or islamic boarding school is still considered being left behind in term of technology mastery, particularly in the use of information technology to education. Whereas, the potential for improvement exists when Siskdiknas Act No. 20 of 2003 Article 30, paragraph 4, placed boarding position parallel with other educational institutions in Indonesia. Now, pesantren are not only identic with as educational institutions that teach religious sciences but also develop general science, including the use of information technology for education. Therefore, pesantren should not waste this opportunity. Pesantren should always update the information they use. With information technology pesantren can be belped disseminate information about the profile, activities and management schools in developing buman resources and education.

Keywords: Pesantren, Technology, Human Resources 


\section{PENDAHULUAN}

Secara historis, pendidikan pondok pesantren lebih menekankan pada aspek pengembangan pendidikan keislaman (salaf). Di pesantren pendidikan keislaman lebih dominan diberikan daripada pendidikan umum, karena pesantren merupakan lembaga pendidikan yang mengajarkan berbagai teori yang dikembangkan dari hipotesa-hipotesa atau wawasan yang bersumber dari alQur'an dan Hadis. Walaupun begitu di tempat tersebut diajarkan pula kitab-kitab kuning yang dapat membekali para santri dalam mengembangkan pendidikan Islam/pesantren model Indonesia (Arifin, 2000: 7).

Pendidikan di pesantren, menekankan kepada terjalinnya hubungan antara manusia dengan Tuhan dan manusia dengan manusia serta ajaran tentang hubungan antara dunia dengan akhirat yang didasarkan pada al-Qur'an dan sunah sebagai sumber acuannya (Rahman, 2005: 11). Sedangkan ditinjau dari peran kelembagaannya merupakan sub sistem dari pendidikan nasional dan secara historis telah memberikan kontribusi yang signifikan bagi kemajuan peradaban Islam di Indonesia. Sebagai lembaga pendidikan yang indigenous (khas Indonesia), pesantren memiliki akar sosio-historis yang cukup kuat, sehingga membuatnya mampu menduduki posisi yang relatif sentral dalam dunia keilmuan masyarakat Indonesia, sekaligus bertahan dan menyesuaikan diri dengan gelombang perubahan zaman. Demikian besar peranan pondok pesantren dalam membangun sejarah kebangsaan Indonesia. Banyak tokoh nasional dan bahkan internasional yang lahir dari lingkungan pondok pesantren, seperti K.H. Hasyim Asyari, Wahid Hasyim dan Natsir. Hal ini membuktikan bahwa pondok pesantren mempunyai kekuatan dan kemampuan strategis untuk menghasilkan manusia berkualitas, memiliki pengetahuan luas, berpikiran maju dan berwawasan kebangsaan yang kuat (Baso, 2012: 163-183).

Terbitnya Undang-Undang Nomor 20 Tahun 2003 tentang Sistem Pendidikan Nasional (Sisdiknas) memberi peluang yang cukup besar bagi pengembangan pesantren. Pasalnya, UU tersebut telah menghapus diskriminasi terhadap pendidikan keagamaan yang berlangsung selama ini. Konkretnya, pendidikan diniyah dan pesantren telah diakui sebagai bentuk pendidikan keagamaan (pasal 30 ayat 4 UU Sisdiknas Departemen Pendidikan RI). Dengan demikian, beberapa kalangan meyakini bahwa nasib lembaga pendidikan yang asli dan tertua di Indonesia ini bakal menjadi "lebih baik". Ada kecenderungan bahwa kini birokrasi pendidikan nasional tidak lagi meminggirkan pesantren dari arus utama kebijakannya.

Berhubungan dengan penerapan teknologi informasi dan komunikasi (ICT), untuk pendidikan pondok pesantren masih terkesan diabaikan baik secara kebijakan maupun perlakuan di lapangan, di zaman postmodern ini, teknologi informasi menjadi bagian yang sangat penting dari kehidupan manusia, termasuk di pesantren. Dewasa ini informasi merupakan "komoditas primer" yang dibutuhkan orang, seiring dengan semakin canggihnya teknologi informasi dan komunikasi. Oleh karena itu, peradaban pada masa sekarang ini merupakan 
peradaban masyarakat informasi sehingga abad ini disebut dengan abad informasi.

Dengan melihat perkembangannya, keberadaan teknologi informasi merupakan suatu hal yang tidak dapat dihindari. Pesantren sebagai lembaga pendidikan yang memiliki pengaruh sangat besar terhadap masayarakat memerlukan teknologi informasi dan komunikasi agar hubungan antara pesantren dengan masyarakat semakin harmonis, berdaya guna dan tersampaikan secara tepat dan cepat.

Sifat khas Indonesia/indegeneusitas pesantren kontras dengan praktik pendidikan lain pada umumnya menyebabkan pesantren dapat menampilkan watak yang khas dan eksotik. Di era globalisasi seperti sekarang ini, pesantren dituntut cepat mengakselerasi dalam berbagai aspek, sebagai konsekuensi logis dari penerapan bigh-tech (berteknologi tinggi), menyebabkan bangsa Indonesia tergiring pada pola interaksi yang amat cepat dan massif dengan negara-negara lain di dunia. Dalam fase masyarakat informasi inilah, pesantren semakin menghadapi tantangan yang tidak ringan dan lebih kompleks dibanding zaman sebelumnya. Untuk itu diperlukan adanya terobosan untuk mulai memperkenalkan serta menerapkan teknologi informasi dan komunikasi di dalam pesantren dan madrasah melalui berbagai metode yang tepat. Karena itu diperlukan pemanfaatan penggunakan teknologi informasi/Information Technology dapat diaplikasikan dalam pesantren sebagai lembanga pendidikan di masyarakat yang dapat memberikan peluang dalam kemajuan Bangsa Indonesia.

\section{PEMBAHASAN}

Pesantren identik dengan Javenese santri place or seminary for students of teology on the islands of Java and Madura. Hal ini berarti pesantren adalah tempat seminar teologi bagi santri di pulau Jawa dan Madura. Sedangkan kata santri, yang ditambah dengan awalan "pe" di depan dan akhiran "an" sehingga menjadi pesantren dimaknai sebagai tempat tinggal para santri untuk mengikuti pelajaran agama Islam. Secara etimologis kata pesantren berasal dari kata pe-santri-an, yaitu "tempat santri" (Manfred, 1983: 6).

Kata pesantren terkadang dianggap sebagai gabungan dari kata "sant" (manusia baik-baik) dengan suku kata "tra" (suka menolong), sehingga kata "pesantren" dapat berarti tempat pendidikan manusia agar menjadi baik. Santri atau murid mendapat pelajaran dari pimpinan pesantren (kiai) dan para guru (ulama atau ustadz). Pelajarannya mencakup berbagai bidang tentang pengetahuan Islam. Secara historis, pesantren adalah suatu lembaga pendidikan Islam tertua yang berfungsi sebagai salah satu benteng pengetahuan umat Islam, pusat dakwah dan pusat pengembangan masyarakat/peradaban muslim Indonesia. Sedangkan istilah "santri" itu sendiri, berasal dari bahasa Tamil, yang berarti "guru mengaji". Santri maksudnya "shastri" dalam bahasa India, yang berarti "orang yang tahu buku-buku suci agama Hindu", atau "seorang sarjana ahli kitab suci agama Hindu". Kata "shastr" berasal dari kata "shastra" yang 
berarti "buku-buku suci", "buku-buku agama" atau "buku-buku tentang ilmu pengetahuan (Zamakhsyari, 1990: 18).

Jika ada sebagian orang yang berpendapat bahwa pesantren itu berhubungan dengan agama Budha terutama dalam konteks asramanya, itu pun dapat dibenarkan. Bagaimanapun juga ada beberapa ahli yang menjelaskan bahwa "Agama Jawa" (abad 8-9 M) merupakan perpaduan antara kepercayaan Animisme, Hinduisme dan Budhisme (Mastuhu, 1989: 7). Di bawah pengaruh Islam, "Agama Jawa" tersebut terutama sistem pendidikannya diambil dan diperbaharui oleh ajaran Islam. Para penyebar agama Islam mengganti nilai ajaran "agama Jawa" tersebut dengan nilai ajaran agama Islam. Model pendidikan "agama Jawa" itu disebut "pawiyatan", berbentuk asrama dan rumah guru. Gurunya disebut "Ki Ajar" di tengah-tengahnya murid yang disebut "cantrik". $\mathrm{Ki}$ ajar dan cantrik atau murid tersebut hidup bersama dalam satu tempat/kampus. Hubungan mereka sangat erat, bagaikan keluarga dalam satu rumah. Ilmu-ilmu yang diajarkan adalah; filsafat, alam, seni, sastra dan pertanian. Semuanya diberikan secara terpadu menjadi pendidikan agama, moral dan kebangsaan (Dewantoro, t.t: 38). Istilah "santri" erat hubungannya dengan kawasan Asia Selatan bukan dengan Arab karena kata santri yang sepadan dengan kata "sastri" berasal dari Bahasa Sansekerta. Artinya adalah "melek huruf". Ia dikonotasikan dengan masyarakat kelas "leterate" atau orang terpelajar. Karena materi yang diberikan berisi pengetahuan agama Islam dan dibaca dari kitab-kitab berbahasa Arab maka diasumsikan juga bahwa santri adalah orang yang tahu agama dan paling tidak mereka dapat membaca al-Qur'an (tanpa syakal/Arab Gundud) serta menumbuhkan sikap yang lebih serius dalam memandang agama Islam (Madjid, 1997: 20). Itulah sebabnya pesantren pun didekatkan dengan budaya Arab.

Penjelasan di atas menegaskan bahwa pesantren itu berbeda dengan lembaga pendidikan Islam lainnya seperti madrasah dan Majlis Ta'lim (Steenbrink, 1991:10). Hal yang membedakan, utamanya karena di dalam pesantren itu terdapatnya pondok atau asrama untuk para santri, yang tidak terdapat pada madrasah atau sekolah pada umumnya.

Tidak jelas kapan pesantren pertama kali berdiri dan siapa yang menggunakan kata kiai dan santri. Semua masih dalam perdebatan, tetapi itu bukanlah sesuatu yang negatif, justru hal tersebut menandakan bahwa pesantren sudah lama melekat pada masyarakat Jawa/Indonesia. Dalam pandangan Steenbrink, pesantren dilihat dari segi bentuk dan sistemnya berasal dari India, karena sebelum Islam berkembang di Indonesia, sistem pesantrian/padepokan, secara umum telah digunakan dalam pendidikan dan pengajaran agama Hindu di Jawa. Setelah Islam berkembang di tanah Jawa, sistem tersebut diadopsi oleh Islam menjadi pesantren. Dengan demikian, dilihat dari bentuknya antara pendidikan Hindu/padepokan dan pesantren terdapat kesamaan asal usul dan perlakuan, seperti adanya penyerahan tanah dari negara untuk kepentingan agama. Sistem pendidikan pesantren tidak dijumpai dalam sistem pendidikan asli 
Makah (Nur Syam, 2005: 93). Akan tetapi pola pendidikan pesantren yang menggunakan bahasa Arab, dapat ditemukan pula di Baghdad saat kota tersebut menjadi pusat kebudayaan Islam. Karena itu, tradisi penyerahan tanah oleh negara yang kemudian menjadi sistem wakaf hadir di wilayah tersebut (Yunus, 1995: 31).

Di Indonesia terutama di Jawa, pendidikan pesantren tidak bisa dilepaskan dari peran Wali Sanga yang hidup sekitar abad 15 - 16 yang menyebarkan agama Islam di tanah Jawa. Maulana Malik Ibrahim (meninggal 1419 di Gresik, Jawa Timur) dikenal "spiritual father"-nya Wali Songo. Dalam tradisi santri Jawa, ia biasanya dipandang sebagai "gurunya guru" (syaikhul masyayikh). Wali Songo adalah tokoh penyebar Islam yang telah berhasil mengombinasikan berbagai tatanan kehidupan masyarakat Jawa dengan nilai-nilai spiritual Islam (Mas'ud, 2002: 3). Para santri tanah Jawa berpandangan bahwa Wali Songo adalah pemimpin umat yang sangat saleh dan dengan pencerahan spiritual-religius mereka, bumi Jawa yang awalnya tidak mengenal agama monotheisme (Islam) menjadi mengenal dan memeluknya.

Berdasar pada keterangan di atas, pesantren dengan segala tradisi pendidikan, pengajaran dan pembinaan wataknya secara kelembagaan mengambil tradisi-tradisi agama lokal seperti Animisme, Hindu dan Budha. Sedangkan secara substansial lembaga yang telah ada tersebut diadaptasi dengan ajaran Islam dengan mengakomodasi ajaran agama lokal yang tidak bertentangan dengan ajaran Islam. Hal ini dilakukan oleh Wali Songo sebagai gerakan "Islam kultural". Gerakan ini dalam prosesnya membutuhkan waktu yang cukup panjang dan bertahap yang kemudian dilanjutkan oleh santri-santri mereka, dan pada akhirnya menjadi pengganti serta penerus Islamisasi tanah Jawa dalam bentuk pendirian pondok pesantren. Gerakan Islam kultural ini dilakukan dengan menekankan rasa saling berdampingan, damai, persatuan dan kesatuan, stabilitas dan harmoni dengan masyarakat sekitar. Dalam perkembangan selanjutnya, pesantren tumbuh dan berkembang di seluruh Indonesia dengan berbagai ciri khas kulturnya, sehingga ada pesantren salafiyyah (lama) dan pesantren khalafiyyah (baru/modern).

Pengajaran ilmu-ilmu keislaman di pesantren, pada umumnya dilaksanakan melalui pengajian kitab-kitab Islam klasik. Namun pada sebagian pesantren, khususnya pesantren khalafiyyah, pengajaran ilmu-ilmu keislaman meskipun ada yang menggunakan kitab-kitab berbahasa Arab namun tidak tergolong ke dalam kitab-kitab klasik. Kitab-kitab Islam klasik yang lebih populer dengan sebutan kitab kuning, ditulis oleh para ulama Islam zaman pertengahan. Kepintaran dan kemahiran seorang santri diukur dari kemampuannya membaca dan mensyarabkan (menjelaskan) isi kandungan kitab-kitab tersebut. Agar bisa membaca dan memahami sebuah kitab, seorang santri dituntut terlebih dahulu memahami dan menguasai ilmu-ilmu alat/bantu seperti: nabwu, sharaf, balaghah, ma'ani, dan bayan. Kitab yang diajarkan antara pesantren satu dengan pesantren lain berbedabeda, karena pesantren memiliki variasi pengajaran keislaman yang bermacam- 
macam, sekaligus disesuaikan dengan karakteristiknya sendiri (Anwar, 2003: 75). Ada pesantren yang dikenal memiliki spesialisasi dalam pengajaran tauhid namun ada pula yang menonjol dalam bidang tafsir-hadis. Ada juga pesantren yang memfokuskan pada takhasus baik fiqih atau syari'ah, nabwu dan sharaf. Ada pula yang disebut dengan pesantren tasawuf, bahkan ada yang khusus menekuni ilmuilmu falaq. Akhir-akhir ini ada pesantren dengan spesialisasi baru seperti: pertanian, pertukangan, keterampilan jasa, koperasi dan pelestarian lingkungan.

Kitab-kitab yang dipelajari meliputi tafsir, hadits, fiqih, ushul fiqih dan tasawuf mulai dari yang tipis sampai yang tebal. Kesemuanya ini digolongkan ke dalam tiga kelompok, yaitu: 1) kitab-kitab dasar, 2) kitab-kitab tingkat menengah, dan (3) kitab-kitab besar (Dhofier, 1990: 50-51). Untuk kitab-kitab yang tergolong tingkat dasar dan menengah diserahkan kepada/diajarkan oleh para ustadz atau badal (asisten) kiai. Sedangkan yang tergolong kitab-kitab besar atau level tinggi, kiai sendiri yang mengajarkannya.

Dalam proses pembelajaran biasanya para santri menggunakan istilah "terjemahan jenggotan". Bentuk terjemahan ini selalu ditulis dalam bahasa Jawa dengan huruf Arab "pegon" yang ditulis menggelantung di bawah teks Arab aslinya. Pola ini digunakan hampir di seluruh Indonesia, termasuk mereka yang tidak berbicara dengan bahasa Jawa, seperti Madura dan Sunda (Dhofier, 1990: 309). Tradisi terjemahan ini sampai sekarang masih dipraktikan di pesantrenpesantren salafiyah. Hal ini dilakukan agar kiai/guru menjadi isnâd (sambung) sehingga diketahui melalui jalur mana santri pernah mempelajari kitab kuning tersebut. Pola penerjemahan kitab kuning khas pesantren ini membuktikan bahwa validitas pesantren salafiyah terletak pada otoritas transmisi ilmu pengetahuan dari kiai kepada santri. Bagi pesantren salafiyah, pengajian kitab kuning mutlak dilaksanakan. Tidak demikian halnya dengan pesantren yang tergolong modern. Bagi pesantren modern, pengajian kitab kuning bukan merupakan prioritas, bahkan ada yang tidak mengajarkan sama sekali.

Pengajian ilmu-ilmu agama diambil dari kitab-kitab yang berbahasa Arab yang dikarang oleh para ulama yang tergolong mutaakhir (tidak disusun pada zaman pertengahan). Misalnya, Pondok Modern Darussalam Gontor Ponorogo, pesantren ini mendakwahkan dirinya sebagai pesantren modern, demikian juga dengan Pondok Pesantren Wali Songo Ngabar Ponorogo tergolong dalam pesantren modern. Di pesantren ini pelajaran agama Islam tidak berdasar kepada kitab kuning, tetapi kebanyakan bersumber dari kitab karangan ulama yang tergolong abad ke-20. Kitab-kitab tersebut ditulis dengan menggunakan bahasa Arab, sehingga para santri dituntut untuk memiliki kemampuan memahami dan menguasai kaidah-kaidah Bahasa Arab, maka kemampuan mendalami dan menguasai kaidah-kaidah Bahasa Arab menjadi syarat mutlak untuk memahami kandungan kitab-kitab tersebut.

Pesantren adalah lembaga pendidikan yang merupakan bagian dari perkembangan sistem pendidikan nasional. Secara historis pesantren tidak hanya identik dengan makna keislaman, tetapi juga mengandung makna keaslian 
Indonesia (indigenous), sebab, lembaga yang serupa pesantren ini sebenarnya sudah ada sejak pada masa kekuasaan Hindu-Budha, yakni padepokan. Para penyebar Islam tinggal meneruskan dan mengislamkan lembaga pendidikan yang sudah ada (Majid, 1997: 3). Di Indonesia, istilah kuttab lebih dikenal dengan pondok pesantren, yaitu sebagai lembaga pendidikan Islam, di dalamnya terdapat seorang kiai (pendidik) dengan menggunakan masjid sebagai tempat menyelenggarakan pendidikan, serta didukung adanya pondok (asrama) sebagai tempat tinggal para santri (Mukti, 1987: 323). Sistem asrama merupakan ciri khas tradisi pendidikan pesantren, yang membedakan dari sistem pendidikan tradisional di masjid-masjid yang berkembang di Indonesia. Area komplek pesantren awalnya adalah milik kiai seorang, tetapi sejalan dengan perkembangan zaman berangsur-angsur berubah menjadi yayasan, badan wakaf atau masyarakat. Walaupun demikian kiai tetap memiliki kekuasaan mutlak atas pengurusan di komplek pesantren. Setiap murid mendapat kesempatan untuk belajar secara langsung dari kiai atau pembantunya, melalui sorogan. Sistem ini biasanya diberikan dalam pengajian kepada murid-murid yang telah menguasai baca alQur'an. Ini merupakan bagian yang paling sulit sebab sistem ini menuntut kesabaran, kerajinan, ketaatan dan kedisiplinan murid. Murid seharusnya sudah paham tingkat sorogan ini sebelum dapat mengikuti pendidikan selanjutnya di pesantren (Dhofier, 1982: 28).

Sebagai lembaga pendidikan Islam, pesantren pada dasarnya hanya mengajarkan ilmu-ilmu agama Islam. Pelajaran agama yang dikaji di pesantren antara lain; (1) al-Qur'an beserta makhraj, tajwîd dan tafsirnya, (2) fiqh dan ilmu ushul fiqh, (3) aqâid dan ilmu kalam, (4) Hadis dan mustholah hadis, (5) bahasa Arab dengan ilmu-ilmu alatnya, seperti nabwu, sharaf, bayân, ma'ani, badi' dan 'arudl, (6) târikh, (7) mantiq, (8) tasawuf (Dhofier, 1982: 107).

Metode pengajaran di pesantren dikenal dengan sorogan, wetonan dan hafalan. Penyampaiannya dengan cara menerjemahkan kitab-kitab tersebut ke dalam Bahasa Jawa kemudian materi tersebut dihafalkan. Metode wetonan disebut juga dengan bandongan. Keduanya merupakan metode kuliah di mana para santri mengikuti pelajaran dengan duduk (lesehan) di sekeliling kiai yang membaca dan menerangkan isi kitab. Santri menyimak kitab masing-masing, dan memberi catatan di bagian yang kosong pada halaman kitab (Mas'ud: 2001: 10 dan Dhofier, 1990: 201).

Istilah wetonan berasal dari bahasa Jawa "wekton" yang berarti "waktu-waktu tertentu" dan mendapatkan akhiran "an". Karena pengajian tersebut diberikan pada waktu-waktu tertentu, yaitu sesudah atau sebelum melaksanakan shalat fardhu. Di Jawa Barat, metode ini disebut dengan "bandungan" sedangkan di Sumatra disebut dengan "halaqah". Sistem ini dikenal juga dengan sebutan "balaghan", yaitu belajar secara berkelompok yang diikuti oleh seluruh santri. Biasanya kiai menggunakan bahasa daerah setempat dan langsung menerjemahkan kalimat demi kalimat dari kitab yang dipelajarainya (Dhofier, 1982: 108). 
Metode sorogan adalah suatu metode di mana santri menghadap kiai, seorang demi seorang secara bergiliran dengan membawa kitab yang akan dipelajari. Kiai membaca dan menerjemahkannya kalimat demi kalimat, kemudian menerangkan maksudnya. Santri menyimak bacaan kiai dan mengulanginya di hadapan kiai sampai memahami maksud isi kitab. Kemudian kiai mengesahkan (Jawa: ngesahi), jika santri benar-benar sudah mengerti, dengan cara memberikan catatan pada kitabnya untuk mensahkan bahwa ilmu tersebut telah diberikan oleh kiai kepadanya. Istilah "sorogan" berasal dari bahasa Jawa "sorog" yang berarti "sodor", dengan mendapatkan akhiran "an" menjadi "sorogan" yang berarti "menyodorkan", yakni menyodorkan kitab ke hadapan kyai atau badal (asisten) nya. Pengajian metode ini merupakan pelimpahan nilainilai sebagai proses delivery of culture di pesantren dengan istilah tutorship atau mentorship (Dhofier, 1982: 108).

Metode hafalan adalah metode di mana santri menghafal teks atau kalimat tertentu dari kitab yang dipelajarinya. Biasanya cara menghafalnya diajarkan dalam bentuk syair atau nadham. Dengan cara ini santri menjadi mudah untuk menghafal, baik ketika belajar maupun saat berada di luar jam belajar. Kebiasaan menghafal merupakan tradisi yang sudah berlangsung sejak berdirinya pesantren.

Dalam hubungannya dengan pengembangan SDM (sumber daya manusia), pesantren diharapkan dapat melahirkan intelektual muslim yang:

1. Selalu berbuat atau bertindak sesuai dengan ketentuan yang diamanahkan oleh al-Qu'ran dan al hadis agar dia selalu dapat menempatkan dirinya sebagai choeruummah yang dapat menjadi tauladan di tengah masyarakat sekelilingnya;

2. Takut kepada Allah SWT dan tidak takut kepada ciptaan-Nya;

3. Ingin menciptakan kemakmuran serta kedamaian di muka bumi;

4. Takut menyebarkan fitnah, berani menegakkan kebenaran dan keadilan;

5. Dalam mengerjakan apapun hanya dalam rangka mencari ridha Allah SWT, karena sadar benar tentang adanya kebahagiaan yang abadi di akhirat;

6. Memiliki sifat-sifat siddîq, amânah, tablîqh, fathânah, serta selalu tawâdlu dan tafakkur.

7. Memiliki rasa ingin tahu yang tinggi sehingga mampu menemukan halhal baru yang bermanfaat bagi manusia.

Untuk mewujudkan harapan di atas kunci utamanya terletak di tangan para pendidik, yang harus memiliki karakter kuat, sabar, istiqamah, tegas, penuh perhatian, adil serta menguasai benar-benar materi yang ingin disampaikan. Di tengah pergaulan masyarakat informasi, pesantren 'dipaksa' memasuki ruang kontestasi dengan institusi pendidikan lainnya. Maraknya pendidikan berlabel luar negeri pun menambah semakin ketatnya persaingan mutu lulusan pendidikan. Kompetisi yang kian ketat itu, memosisikan institusi pesantren 
untuk mempertaruhkan kualitas out-put pendidikannya agar tetap unggul dan menjadi pilihan masyarakat, terutama umat Islam. Ini mengindikasikan, bahwa pesantren perlu banyak melakukan pembenahan internal dan inovasi baru agar tetap mampu meningkatkan mutu pendidikannya.

Kebutuhan akan SDM yang berkualitas, dengan sendirinya selalu terjadi, sebab ia adalah hasil dari interaksi antara pertumbuhan ekonomi, perubahan sosial budaya termasuk kedalaman pengamalan ajaran dan nilai-nilai agama serta perkembangan iptek. Apabila dilaksanakan secara terencana dan terkendali, ketiga proses tersebut menjadi sinergis. Dalam hal ini pembangunan ekonomi tidak secara otomatis menjamin terdapatnya peningkatan kualitas SDM. Namun perkembangan SDM yang berkualitas dapat mempercepat pertumbuhan ekonomi. Tuntutan zaman menghendaki agar pembentukan kepribadian harus dilakukan secara lebih seksama, sehingga SDM diarahkan untuk menghadapi tantangan zaman dan di waktu yang bersamaan menjadi insan yang taat menjalankan ajaran agamanya. Dengan demikian pondok pesantren harus turut serta mewujudkan manusia Indonesia yang beriman dan bertakwa, yang berilmu dan beramal; juga membentuk manusia Indonesia yang modern. Peran pondok pesantren sebagai agen perubahan seperti di masa yang lalu (pra kemerdekaan) yang mampu berjuang demi bangsa dan negaranya dapat diraih kembali, yakni dengan menjadikan pondok pesantren sebagai pusat pendidikan dan pengembangan budaya modern.

Peran pondok pesantren dalam membangun masyarakat Indonesia sangat besar, terutama pada akar rumput. Oleh karena itu, proses modernisasi masyarakat dan bangsa Indonesia, akan dapat lebih cepat apabila dipelopori oleh pondok-pondok pesantren. Untuk itu pondok pesantren perlu menyesuaikan pola pendidikan dan pengajarannya serta kehidupan para santrinya agar pondok pesantren dapat menjadi lembaga masyarakat yang mandiri tetapi tetap berada di atas landasan firman Allah SWT dan hadis Nabi Muhammad SAW.

Dengan melihat sisi historisnya mengenai sistem pendidikan di pesantren, maka perlu ada perubahan baik dari pesantren itu sendiri, masyarakat dan pemerintah untuk segera menyesuaikan dengan perkembangan dan tuntutan zaman. Bagaimanapun juga, sebelumnya banyaknya lulusan pesantren yang memiliki integritas dan intelektual yang tinggi, baik dalam hal agama maupun dalam hal pengetahuan umum (Gus Dur, Nurkhalis Madjid dan Amien Rais). Oleh karenanya, sudah seharusnya pemerintah memperhatikan pendidikan pesantren di Indonesia agar dapat terus membangun bangsa.

Pembaruan dalam pelbagai aspeknya seperti dalam kurikulum, saranaprasarana, tenaga kependidikan (pegawai administrasi), guru, manajemen (pengelolaan), sistem evaluasi dan teknologi harus terus dilakukan bersama-sama oleh seluruh elemen masyarakat. Pesantren bukan hanya milik umat Islam saja tetapi juga milik seluruh komponen bangsa Indonesia. Jika aspek-aspek tersebut tidak mendapatkan perhatian yang serius dan proporsional, menyesuaikan dengan tuntutan zaman (dimodernisasi) maka eksistensi pesantren akan 
terancam. Ia pun tidak bisa lagi bersaing di masa kini maupun di masa yang akan datang. Dengan begitu, pengembangan pendidikan pesantren tidak saja dilakukan dengan cara memasukan pengetahuan non-agama, melainkan agar lebih efektif dan efisien, praktik pengajaran pun harus menerapkan metodologi yang lebih baru dan modern. Sebab, ketika didaktik-metodik yang diterapkan masih terpusat pada cara-cara lama yang sudah ketinggalan zaman, maka pesantren sulit untuk berkompetisi dengan institusi pendidikan lainnya.

Undang-Undang Nomor 20 Tahun 2003 tentang Sistem Pendidikan Nasional (Sisdiknas) telah menghapus diskriminasi terhadap pendidikan keagamaan yang berlangsung selama ini. Pendidikan diniyah dan pesantren telah diakui sebagai bentuk pendidikan keagamaan (pasal 30 ayat 4). Penerapan dari UU di atas dapat memberikan peluang besar terhadap segala aktivitas pendidikan di pesantren agar dapat dengan leluasa membentuk manusia Indonesia menjadi insan yang mampu memahami, menghayati dan bertingkah laku secara Islami. Ranah kognitif, afektif dan psikomotorik santri benar-benar diarahkan untuk menjadi manusia yang taat beragama dan saleh, baik secara individual maupun sosial. Walaupun belakangan ini ada pesantren yang telah memasukkan pendidikan formal setingkat SLTP/MTs, SMU/SMK/MA dan bahkan ada yang membuka perguruan tinggi, namun tetap mengutamakan penghayatan ajaran Islam yang komprehensif.

\section{Pesantren di Era Teknologi dan Informasi}

Di Abad ke-21 ini, bangsa-bangsa di dunia sedang berlomba-lomba mengembangkan berbagai teknologi strategis. Dampak pengembangan teknologi ini menyebabkan kompetisi perekonomian di satu sisi menjadi semakin tajam dan di sisi lain semakin meluas. Keadaan tersebut sebagai akibat dari cepatnya perkembangan teknologi informasi dan transportasi yang menyebabkan makin mudahnya bagi negara-negara untuk mengakses informasi bisnis, industri dan teknologi. Perkembangan teknologi yang semakin canggih dan arus modal yang semakin cepat berputar dan meluas memungkinkan banyak orang memiliki, membeli dan menggunakannya, walaupun masih belum mampu menguasai atau mengembangkan sendiri teknologi tersebut. Kesempatan memanfaatkan dan menguasai teknologi dan bisnis juga bisa diraih oleh negara-negara berkembang termasuk Indonesia. Sejak dasawarsa 1980-an, kemajuan teknologi dan pertumbuhan industri yang begitu pesat di berbagai bidang telah berdampak dan secara dramatis mengubah pengertian konseptual kita tentang jarak, waktu, budaya, gaya hidup dan perilaku.

Karena interaksi antar bangsa semakin meningkat maka akses terhadap nilai-nilai baru, terutama nilai-nilai budaya dari luar masyarakat Indonesia semakin besar. Perekonomian nasional pun semakin membuka diri terhadap perkembangan perekonomian dunia dan kini di era milenium ke III, dampaknya sangat terasa terutama pada kehidupan yang makin kompetitif. Sementara sumber daya alam yang dimiliki bangsa Indonesia sangat terbatas dan SDM pun 
belum kompetitif. Krisis moneter yang menimpa Indonesia dan beberapa negara lain, yang disebut sebagai krisis Asia bahkan sekarang Eropa, juga merupakan akibat dari keterbukaan/globalisasi ekonomi.

Di era baru ini (informasi dan teknologi), Bangsa Indonesia pun telah mentransformasi beberapa segi kehidupan sosial dan budaya secepat mungkin dan semendasar mungkin termasuk dalam bidang teknologi. Proses transformasi dari era lama ke era baru ini sedemikian rupa telah berpadu dengan proses pembaruan, yang dikenal dengan reformasi. Reformasi adalah bentuk koreksi atas kekeliruan di masa lalu agar bisa menatap masa depan yang lebih baru dan menjanjikan. Tetapi, jika bangsa ini tidak hati-hati dalam mengelola perubahan tersebut maka akan terjadi benturan-benturan besar yang dapat merusak nilainilai bangsa yang selama ini telah terpelihara dengan baik seperti semangat persatuan dan kesatuan. Di sini peran agama dalam melandasi kehidupan berbangsa dan bernegara menjadi sangat penting, terutama dalam rangka membendung nilai-nilai yang bertentangan dengan budaya dan kepribadian bangsa Indonesia yang telah terbentuk dan teruji dalam waktu yang panjang (www.ginandjar.com). Berbagai perubahan tersebut menuntut sikap mental yang kuat, tingkat partisipasi, produktivitas, keefektifan dan efisiensi yang tinggi dari seluruh lapisan masyarakat. Hal ini menunjukkan bahwa tuntutan terhadap pengembangan SDM yang semakin berkualitas dan tangguh, yang mampu mengantisipasi perubahan-perubahan yang terjadi dan mengatasi ekses-eksesnya semakin mendesak untuk dipenuhi. Terpenuhinya SDM yang berkualitas berdampak pada tingkat kecepatan mengakses dan mengolah informasi serta memanfaatkan teknologi untuk kepentingan pembangunan bangsa.

Teknologi informasi dan internet tidak dapat dilepaskan dari bidang pendidikan, termasuk dari pesantren. Di Amerika, internet mulai tumbuh dari lingkungan akademisi (Nerds 2.0.1). Demikian pula Internet di Indonesia mulai tumbuh dari lingkungan akademisi (UI, ITB dan UGM). Ke depan internet pun bisa berkembang di lingkungan pesantren.

Adanya internet di pesantren memudahkan santri mengkases informasi dan ilmu pengetahuan. Mengakses sejumlah informasi dan ilmu pengetahuan seharusnya bukan menjadi hal yang tabu lagi bagi pesantren. Santri yang telah dibekali dengan pelbagai pengetahuan dan penghayatan tentang akhlak mestinya lebih siap menghadapi dampak negatif dari internet dibanding dengan siswa lain pada umumnya. Perangkat sufisme yang dimilikinya mestinya menjadi semacam filter alamiah dalam menangkal pelbagai informasi negatif dari internet.

Perpustakaan merupakan salah satu sumber informasi yang mahal harganya. Adanya Internet memungkinkan kegiatan pesantren dapat berjalan dengan baik, termasuk dalam memberikan pertolongan dalam penelitian tugas akhir di kalangan santri dan santriwati. Tukar menukar informasi atau tanya jawab dengan pakar dapat dilakukan melalui internet baik melalui face book, email, twitter dan blog. 
Teknologi Informasi dan Komunikasi (TIK) telah merevolusi cara hidup manusia, cara berkomunikasi, belajar, bekerja, berbisnis menjadi sangat praktis, efektif dan efisien. Era informasi memberikan ruang lingkup yang sangat besar untuk dapat mengorganisasi segala kegiatan melalui cara-cara baru, inovatif, instan, transparan, akurat, tepat waktu, lebih baik dan memberikan kenyamanan yang lebih dalam mengelola dan menikmati kehidupan termasuk di pesantren. Salah satu manfaat yang dirasakan oleh pesantren adalah adanya tuntutan perbaikan mutu dan kualitas penyelenggaraan pembelajaran karena ditunjang oleh berbagai fasilitas yang sebagian besar memanfatkan teknologi informasi dan komunikasi (Pannen P, 2005: 29).

Teknologi Informasi dan Komunikasi (TIK) hadir sebagai bentuk tanggapan terhadap perubahan lingkungan di luar dunia pendidikan, mulai lingkungan sosial, ekonomi, teknologi, sampai politik, yang mengharuskan dunia pendidikan memikirkan kembali bagaimana perubahan tersebut mempengaruhinya sebagai sebuah institusi sosial dan bagaimana harus berinteraksi dengan perubahan tersebut agar tidak tertinggal dengan isu-isu yang berasal dari lingkungan luar tersebut. Dengan hadirnya TIK, penyebaran informasi menjadi semakin cepat dan mungkin bisa menjadi tak terkendali, apabila tidak ada aturan-aturan yang membatasi tentang informasi-informasi mana saja yang memang bisa dan layak di akses oleh publik, dan informasi mana yang tidak. Cepatnya penyebaran informasi ini, telah mengubah pola pikir manusia sebagai bentuk respons terhadap cepatnya penyebaran informasi tersebut (Mohandas, R. 2003: 25-27). Jika ditelaah lebih dalam lagi, sejauh mana intervensi TIK dalam sektor pendidikan pesantren, maka akan timbul sebuah pertanyaan, yaitu bagaimana sebenarnya TIK telah mereformasi atau memodernisasikan pendidikan pesantren, sehingga kualitas dan mutu pesantren bisa lebih baik dibandingkan dengan pendidikan konvensional.

Ada tiga hal penting yang harus dipikirkan ulang sehubungan dengan modernisasi di dalam sistem pendidikan pesantren: (1) bagaimana kita belajar (bow people learn); (2) apa yang kita pelajari (what people learn); (3) kapan dan di mana kita belajar (where and when people learn). Menurut Resnick, M. (2002). Dengan mencermati ketiga pertanyaan tersebut dan potensi TI yang bisa dimanfaatkan untuk memoderninasi pesantren maka ia harus selalu meng-up date informasi-nformasi yang mereka pergunakan. Selain itu, dengan teknologi informasi, pesantren dapat terbantu dalam melakukan penyebaran informasi mengenai profil, kegiatan dan manajemen pesantren dalam pengembangan SDM dan pendidikan. Agar dunia pendidikan Indonesia terrmasuk pengembangan SDM dan pendidikan pesantren dapat lebih berkembang dan maju, maka pemerintah melalui Jardiknas (Jejaring Pendidikan Nasional) dan ICT Center dapat membuka akses seluas-luasnya terhadap informasi yang berkaitan dengan pendidikan dan memberikan kesempatan bagi seluruh anak Indonesia untuk mengikuti pendidikan yang layak dan berkualitas, serta memberikan 
pemberdayaan kepada para peserta didik dalam proses pembelajaran, dengan memberlakukan Student Centered Learning/e-Learning gratis.

Program IT di pesantren sejalan dengan program Jardiknas yang diluncurkan Presiden Susilo Bambang Yudhoyono pada bulan Maret 2007. Jaringan berbasis internet ini ditujukan untuk menghubungkan 533 pusat di 33 provinsi, 441 kota/kabupaten, dan lebih 3.600 sekolah menengah atas, lebih dari 84 universitas, dan 61 kantor pendidikan di seluruh negeri. Hingga sekarang, jaringan internet telah dikembangkan di 10 provinsi di Jawa, Sumatera Barat, Kalimantan Selatan, Bali dan Sumatra Selatan. Jaringan sudah diinstal di 25\% dari seluruh SMA/SMK/Madrasah Aliyah di seluruh Indonesia. Pada jenjang universitas, jaringan tertentu sudah dibangun dengan nama Inherent (Indonesan Higher Education Network). Spektrum permasalahan yang luas mulai dari pendidik dan peserta didik, rehabilitasi sekolah, hingga kondisi geografis memang telah mendorong pengembangan jaringan berbasis ICT, termasuk di pesantren.

Indonesia merupakan negara dengan penduduk keempat terbesar di dunia dengan 247 juta jiwa dan dengan keanekaragaman etnis, geografi, bahasa-bahasa lokal dengan 17 ribu pulau. Kondisi ini telah membuka jalan bagi satu pertukaran dan pengiriman pengetahuan, perspektif dan pengalaman dengan memanfaatkan ICT. Karena itu, pendidikan jarak jauh untuk transformasi masyarakat Islam melalui pesantren akan membantu memperluas ruang lingkup Jardiknas pemerintah. Beberapa pesantren yang sudah mengambil bagian dalam proyek ini adalah:

1. PP Hasyim Asy'ari di Jepara (Jawa Tengah),

2. PP Raudhatul Falah di Rembang (Jawa Tengah),

3. PP Al Kinaniyah di Jakarta Timur (DKI Jakarta),

4. PP An Nizamiyyah di Pandeglang (Banten),

5. PP Miftahulhuda Al Musri' di Cianjur (Jawa Barat)

6. PP Al Mizan di Majalengka (Jawa Barat),

7. PP Nurul Jadid di Probolinggo (Jawa Timur)

8. PP Nurul Islam di Jember (Jawa Timur).

Sebagian dari pesantren di atas dipilih karena angka kemiskinan yang tinggi, angka partisipasi sekolah yang rendah, indeks pembangunan manusia yang rendah; dan sebagian juga karena faktor jaringan yang sudah terbentuk antara International Center for Islam and Pluralism (ICIP dan Ford Foundation) (www.pesantrenglobal.or.id).

Sadar atau tidak, informasi bukan hanya kebutuhan, melainkan juga dapat menjadi sumber kekuatan. Teknologi informasi dapat menjadi alat terpenting untuk memanipulasi kehidupan sekaligus menjadi alat kendalinya. Siapa yang menguasai informasi dialah penguasa masa depan. Di tangan segelintir orang meyakini bahwa kekuatan baru masyarakat bukan uang, melainkan informasi di tangan banyak orang (The new source of power is not money in the hand of a few, but information in the hand of many). Wujud dari teknologi informasi yang banyak 
digunakan oleh manusia saat ini diantaranya adalah komputer dan perangkat lainnya seperti internet (bandwidht, jaringan, wireless, hardware dan software).

Itulah teknnologi informasi, khususnya komputer dan internet yang menjadi bagian penting dalam kehidupan kita, termasuk untuk pengembangan pesantren. Peranan teknologi informasi sangat dibutuhkan oleh pesantren dan dapat digunakan sebagai media otomatisasi informasi dan komunikasi dalam konteks da'wah bil hikmah wal manidloh serta amar makruf nabyi munkar. Teknologi pun dapat mempermudah proses pembelajaran. Menepis anggapan bahwa santri dan pihak pesantren itu gagap terhadap kemajuan teknologi, sebagian merespons dan mengantisipasinya dengan menyikapi dengan pernyataan bahwa era cyberspace di masa depan telah menjadi keniscayaan. Bagaimanapun juga, pesantren bukanlah sebuah camp yang harus steril atau tertutup dari akses luar. Pada gilirannya kelak, pesantren dalam batas-batas tertentu akan perlu diketahui akuntabiltas dan transparansi aktivitasnya oleh para pemegang kepentingan. Hal ini juga perlu untuk tetap menjaga kepercayaan publik kepada pesantren.

Lembaga pesantren dari dahulu hingga sekarang atau di masa yang akan datang masih diyakini berperan positif dalam mengadaptasi bahkan mengubah zaman. Pesantren adalah "center of excellent" atau pusat tempat berlangsungnya proses pembelajaran generasi yang akan datang terhadap ilmu-ilmu keislaman dengan metodanya yang khas. Di sini, kiai sebagai figur sentral (sebagai guru, orang tua, pembimbing, penyelenggara pendidikan dan pemilik pesantren) rela berkorban tanpa menuntut imbalan dari siapa pun. Pesantren dapat menjadi alternatif pendidikan yang berbiaya murah, yang mampu membentuk kemandirian individu dan masyarakat, tanpa tergantung kepada alokasi APBD/APBN. Dengan sendirinya, pesantren menjadi sangat otonom dari pengaruh luar yang tidak jelas. Dari sisi kepemilikan sumber daya informasi dan komunikasi keislaman, pesantren memilki otoritas yang andal. Pesantren mempunyai jalur sanad yang jelas dan dapat dipertanggungjawabkan validitasnya.

Lembaga pesantren juga berperan menjadi "center of social change", yaitu agen atau pusat perubahan masyarakat. Sistem (input-procces-output-feed back) di pesantren dapat diharapkan menghasilkan nilai tambah sosial yang tinggi. Di pesantren, agama, ideologi, politik, sosial, ekonomi, budaya, hukum dan pertahanan, bahkan teknologi tepat guna semuanya dipelajari. Dengan demikian pesantren dapat diharapkan menjadi wahana peningkatan kualitas manusia dengan berupaya mengentaskan kemiskinan, kebodohan, sadar lingkungan dan pemelihara moral atau akhlak terpuji yang sudah langka akibat dari pengaruh negatif perubahan zaman. Pesantren bukan hanya melatih kesalehan individual tetapi juga sosial sehingga secara sistemik dapat memberikan multiflier effect dan competitive advantage. Sumber daya manusia Indonesia hendaknya selalu terbarukan sehingga masyarakat Indonesia siap menjadi masyarakat madani, baldatun thoyyibatun wa robbun ghofûr. 


\section{SIMPULAN}

Pendidikan di pesantren, dilihat dari sejarahnya, sudah banyak mengalami perubahan terutama dalam hal mencetak ilmuwan/ulama baik dalam hal agama maupun pengetahuan umum. Perkembangan zaman dan kemajuan teknologi informasi ternyata dapat mengubah secara perlahan paradigma pesantren yang kini jauh lebih peka terhadap perubahan dan perkembangan ilmu pengetahuan. Dalam aspek kebijakan pasal-pasal tertentu menunjukkan adanya pembelaan terhadap sistem pendidikan pesantren dalam konteks pendidikan nasional (UU Sistem Pendidikan Nasional No 20 tahun 2003). Dalam menjalankan perannya, pesantren berupaya memajukan ilmu pengetahuan, teknologi informasi dan komunikasi. Semua digunakan untuk menunjang kelancaran proses pengelolaan pesantren dan peningkatan citra positif lembaganya. Meskipun teknologi informasi di dunia maya sangat beresiko ketika tidak dikelola dengan baik namun ia sangat dibutuhkan oleh pesantren. Semua bergantung pada sikap manusia sebagai pelakunya. Teknologi informasi adalah sarana atau washîlah yang berdasarkan tujuannya diciptakan untuk menciptakan kemaslahatan agama, akal, jiwa, harta dan keturunan/generasi di masa datang. Visi baru ini, dapat menginspirasi secara kuat terhadap keberadaan pesantren di Indonesia dalam mencetak generasi yang cerdas dan responsif terhadap kemajuan ilmu dan peradaban dunia. Pesantren adalah lembaga pendidikan yang sangat kompleks baik dalam konteks ilmu pengetahuan, sosial, budaya, bangsa dan alam semesta.

\section{DAFTAR PUSTAKA}

Anwar, Miski. 2003. Tradisi Pesantren di Tengah-tengah Transpormasi Sosial. Menggagas Pesantren Masa Depan Suara Santri Untuk Indonesia Baru Yogyakarta: Qietas.

Arifin H.M,. 2000. Ilmu Pendidikan Islam.Jakarta: Bumi Aksara.

Baso, Ahmad. 2012. Akar Pendidikan Kewarganegaraan di Pesantren. Media Pendidikan Jurnal Pendidikan Islam. Volume: XXVII, Nomor 2.

Dewantoro, Ki Hajar Taman Siswa tt. Yogyakarta. PN Majlis Luhur Taman Siswa.

Dhofier, Zamakhsyari. 1982. Tradisi Pesantren, Studi Tentang Pandangan Hidup Kiyai. Jakarta: LP3ES.

Dhofier, Zamakhsyari. 1990. Tradisi Pesantren, Studi Tentang Pandangan Hidup Kiyai. Jakarta: LP3ES.

Madjid, Nurcholis. 1997. Bilik-bilike Pesantren: Sebuah Potret Perjalanan.Jakarta: Paramadina.

Mas'ud, Abdurrachman. 2002. Dinamika Pesantren dan Madrasab Yogyakarta: Pustaka Pelajar.

Mohandas, R. 2003. ICT and e-Learning in Indonesia. Presentasi di Tainan, Taiwan, $25-$ 27 Maret. Contob perubahan pola pikir tersebut adalab labirnya e-mail yang mengubah cara berkirim surat, e-business atau e-commerce yang telah mengubah cara berbisnis dengan segala turunannya, termasuk e-cash atau e-money 
Mukti, Ali 1987. Pembaharuan Sistem Pendidikan dan Pengajaran Pondok Pesantren Dalam Rangka Merealisasikan Pendidikan Nasional' dalam suara Muhammadiyah.

Nata, Abudin. 2001 Filsafat Pendidikan Islam Jakarta: Logos.

Pannen, P. 2005. Pemanfaatan ICT dalam Pembelajaran. Presentasi pada Seminar Sun Commitment in Education and Research Industry, Jakarta: ERCI.

Resnick, M. 2002. Rethinking Learning in the Digital Age. Dalam Porter, M. E., Sachs, J. D., dan McArthur, J. W. The Global Information Technology Report 2001-2002: Readiness for the Networked World.

Shaleh, Abdul, Rahman. 2005. Pendidikan Agama dan Pengembangan watak Bangsa. Pendidikan Islam mengajarkan bagaimana bubungan manusia dengan tubannya. Jakarta: Raja Grafindo Persada.

Syam, Nur. 2005. Pengembangan komunitas pesantren dalam dakwah pemberdayaan masyarakat paradikma aksi Metodologi Mob Ali Aqira, dkk (et), Yogyakarta: Pustaka Pesantren.

Steenbrink, K. A.1991. Pesantren, Madrasah, Sekolah: Pendidikan Islam Dalam Kurun Modern, Jakarta: LP3ES.

UU Sukdiknas 2008. Departemen Pendidikan RI. Jakarta: Pustaka Pelajar.

www. educationartikel.com Membongkear Tradisionalisme Pendidikan Pesantren; "Sebuah Pilihan Sejarah, diunduh pada tanggal 05 April 2010 "

www.ginandjar.com diunduh tanggal 08 April 2010

www.pesantrenglobal.or.id diambil pada Rabu, 07 Mei 2010 || 22 Rabiul Akhir 1431 Hijriah

Yunus, Mahmud. 1995. Sejarah Pendidikan Islam di Indonesia (Jakarta Mutiara Sumber Widya.

Ziemek, Manfred. 1983. Pesantren Dalam Perubahan Sosial. Jakarta: Perhimpunan Pengembangan Pesantren dan Masyarakat (P3M). 